\title{
Special issue: Does policy implementation in gender equality policy matter in France-a cross sectoral approach
}

\author{
Amy G. Mazur ${ }^{1}$ \\ Published online: 18 March 2020 \\ (c) Springer Nature Limited 2020
}

This is my third issue since taking over from Robert Elgie as editor, after his unexpected passing last July. It is very special to me for a variety of reasons.

First and foremost, it is yet another tribute to Robert's imprint on the study of French Politics in a Comparative perspective. Since Robert first co-founded the journal 18 years ago, he made an effort to publish the full range of work on French Politics, including research scholarship on gender and politics. Indeed, he went out of his way to support many emerging scholars in this area and worked to not only have individual articles on politics and gender in France but also special issues. Palgrave has very kindly made the most recent articles in this area available for complimentary access on our website as well.

This special issue is particularly poignant for me since I was guest editor and had been working with Robert on it for over 2 years. Thus, finally producing this double issue truly marks this part of Robert's scholarly leadership with regard to promoting politics and gender scholarship and women who mostly conduct it.

The second reason this double issue is important to me is that it is the first time the Gender Equality Policy in Practice Network has applied its framework and published empirical case analyses. With Isabelle Engeli (Exeter University), I have co-convened GEPP since 2013. Our aim has been to systematically study the postadoption phases and outcomes of gender equality policy in democracies over the past 25 years in order to build a theory of gender equality policy success. We currently have two country teams-Germany and France, and three sub-issues teamsemployment, elder care and political representation - that are working on the project in 25 plus countries, with over 100 researchers involved.

The authors contributing to this issue make up the French Team, and we have been working on data collection and analysis since 2015 . Thus, the seven case analyses of gender equality policy implementation in France and the comparative analysis of the results in a separate article, by Isabelle and I, will contribute to the larger ongoing effort to collect data on and develop a theory of gender equality policy

Amy G. Mazur

mazur@wsu.edu

1 Moscow, USA 
implementation. As such, this project is a part of Robert Elgie's life work on promoting the study of French Politics as it fits into larger Comparative Politics efforts.

The two review articles after the GEPP section of the double issue compliment the special issue by focusing on issues of inequality in the elite as well as symbolic politics, given its importance in understanding government action on gender equality that has been labelled symbolic, outputs without any concrete results. Thus, this double issue is a rich stand-alone publication on cutting edge issues in the study of gender and inequalities as they relate to France and Comparative Politics more broadly speaking.

The final reason that this double issue is special is that this will mark the formal association between the French Politics Group of the American Political Science Association and the journal. I am co-convener with Vincent Pons (Harvard University) of the FPG group. This means that we will be able to include the news of the FPG in the journal and have more opportunities for members of the FPG and the scholars who present each year at the APSA meeting to contribute to the journal. We send out a newsletter each year, put together at least two panels at the APSA meetings in the fall and have three different awards: the Frank L. Wilson Best Paper Award, the Stanley Hoffman Award for Best Article on French Politics and the Georges Lavau Dissertation Award. This year, we are making a call for dissertation submissions which can be nominated or self-nominated. So with this issue, we start a regular section called FPG news. One of the best things about the group is that membership is free!! Just contact me at mazur@wsu.edu, if you would like to become a member and we will add you to our email list for the annual newsletter.

And in general, I am always happy to field questions and hear from our readers, authors and reviewers, so please do not hesitate to contact me.

Many thanks for your ongoing support of the journal and the study of French Politics.

Amy G. Mazur

Lead Editor

Moscow Idaho February 26th, 2020

Publisher's Note Springer Nature remains neutral with regard to jurisdictional claims in published maps and institutional affiliations. 